\title{
Contribution of body reserves to milk production in underfed dairy ewes
}

\author{
A Agus 1,2, F Bocquier 1 \\ 1/NRA, Laboratoire Sous-nutrition des ruminants, Theix, 63122 St-Genès-Champanelle, France ; ${ }^{2}$ Faculty of \\ Animal Husbandry, Gadjah Mada University, 55281 Yogyakarta, Indonesia
}

During a period of undernutrition, lactating ruminants can mobilize body reserves, mainly lipids, to maintain milk production. This ability to sustain milk production through body energy mobilization is well documented in dairy cows, but little is known in dairy ewes.

Lacaune ewes $(n=24)$ at $47 \mathrm{~d}$ post-lambing (d 0 ), were assigned to groups of either High $(\mathrm{H})$ or Low (L) level of energy intake i.e. resp 104 and $84 \%$ of energy requirements (INRA, 1988), while protein requirements were met (resp $111 \%$ and $106 \%$ ). Diets were individually adjusted twice a week to previous milk yield and refusals were controlled. Diets consisted of variable proportions of hay and of straw, completed with concentrate of which proportion (DM) in all diets was kept constant $(31 \%)$. Nutritive value of ingested diets was calculated from chemical analyses of feeds and in vivo digestibility of representative diets given to wethers. Ewes were weighed weekly and milk energy output was derived from milk yield and milk composition (fat and protein) measured twice a week. In vivo body composition was estimated indirectly using deuterium oxide method at the beginning $(d+5)$ and the end of the trial $(d+32)$. The results were analysed using variancecovariance analysis.

Pre-trial mean milk yields were of $2.4 \pm 0.37 \mathrm{l} / \mathrm{d}$ in both groups and body weights were respectively 75.4 and $74.2 \mathrm{~kg}( \pm 8.5 ; \mathrm{ns})$ for $\mathrm{H}$ and $L$ groups. At the end of the trial, $H$ ewes still produced $1.47 \mathrm{l} / \mathrm{d}$ milk, whereas in the $\mathrm{L}$ group milk yield was $24 \%$ lower (i.e. $1.11 \mathrm{l} / \mathrm{d}$; $\mathrm{P}<0.001)$. Mean milk yield was $17.5 \%$ lower in underfed vs well-fed ewes (1.33 vs $1.61 \mathrm{l} / \mathrm{d}$; $P<0.001)$. Body weight losses were more important in $L$ vs $H$ group $(-172$ vs $-73 \mathrm{~g} / \mathrm{d}$; $P<0.001)$. Milk fat content was markedly increased $(H: 67$ vs $L: 72 \mathrm{~g} / \mathrm{l} ; \mathrm{P}<0.006)$ by energy restriction, but milk protein content was unaffected $(49 \pm 0.5 \mathrm{~g} / \mathrm{l} ; \mathrm{ns})$.

Using $\mathrm{MEm}=0.4 \mathrm{MJ} \mathrm{ME} / \mathrm{kg} \mathrm{BW} 0.75$ (INRA, 1988), global efficiencies $\left(k_{1}(t)\right)$ of transformation of available metabolizable energy (i.e. ME intake - ME maintenance + measured body energy changes) into milk energy were 0.61 and 0.60 (Table). These values of $k_{1}(t)$ are in general agreement with previous results obtained on suckled and milked ewes (Geenty and Sykes, 1986, J Agric Sci Camb 106, 351367). As body energy variations were almost zero $(P>0.95)$ in High group (Table), the global efficiency $k_{\perp}$ ( $\left.t\right)$ can be considered as partial efficiency i.e. $k_{1}$ which is equal to 0.61 . This $k_{l}$ is very close to classical value found for NEL systems settled on dairy cattle data. Using 0.61 for energy balance of the L group, the efficiency of transformation of body energy into milk $\left(k_{r}\right)$ is then lower $(0.58)$ than the $k_{r}(0.80)$ generally found in dairy cattle, but already seen by Geenty and Sykes.

This experiment shows that after one month of $16 \%$ energy deficit, body energy mobilized can represent up to $39 \%(4.46 \times 0.58 / 6.6)$ of total energy milk output.

\begin{tabular}{lc}
\hline Energy allowance & HIGH \\
\hline ME intake $(\mathrm{MJ} / \mathrm{d})$ & $23.1^{\mathrm{a}}$ \\
ME maintenance $(\mathrm{MJ} / \mathrm{d})$ & $10.1^{\mathrm{a}}$ \\
Milk energy output $(\mathrm{MJ} / \mathrm{d})$ & $8.0^{\mathrm{a}}$ \\
Body energy change $(\mathrm{MJ} / \mathrm{d})$ & $-0.04^{\mathrm{a}}$ \\
Global efficiencies $\left(\mathrm{k}_{\mathrm{l}}(\mathrm{t})\right)$ & $0.61^{2}$
\end{tabular}

\begin{tabular}{cc} 
LOW & RSD \\
\hline $16.1^{\mathrm{b}}$ & 0.89 \\
$9.5^{\mathrm{b}}$ & 0.98 \\
$6.6^{\mathrm{b}}$ & 0.29 \\
$-4.46^{\mathrm{b}}$ & 0.59 \\
0.60 & -
\end{tabular}

$a, b$ Means with different superscripts are significantly different $(P<0.05)$ 